\title{
Socio-Economic Scale (SES) as a Measure of Economic Well-Being: A Case in Barangay Lumbia, Cagayan De Oro City, Philippines
}

\author{
Ma. Kresna D. Navarro \\ Economics Department, Xavier University-Ateneo de Cagayan, Cagayan de Oro Philippines 9000 \\ mnavarro@xu.edu.ph
}

Doi:10.5901/mjss.2015.v6n2p103

\begin{abstract}
In recent years, there have been increasing concerns on the adequacy of traditional macroeconomic statistics, like gross domestic product (GDP) as measures of current and future living conditions. Cases that made GDP an inaccurate measure for economic wellbeing rouses inquiry to utilize the information gathered from Community Based Monitoring System (CBMS) of the 629 respondents of 30 sitios of Barangay Lumbia. The barangay is one of the upland barangays in Cagayan de Oro City, Philippines. Faster pace of economic activity is visible nearer the barangay hall or the city main road where schools, barangay hospitals, church and few business establishments are situated. Few kilometers away from the main political and business zone, activities are slower and laidback while support services are either insufficient or non-existent. Study explore on the socioeconomic condition of the residents of the 30 sitios by looking into the four socioeconomic components: poverty level, income, educational attainment and housing tenure. To further the analysis, the research derived the standardized score of the four socioeconomic components and combined them into a single socioeconomic scale normalized to a base of 100. Socioeconomic scores are reported on a seven-point categorical scale. Findings indicate that residents in the sitios with poor socioeconomic status as sitios with low socioeconomic scale. Results further signifies that the greatest number of the residents in the community has low capability to collectively sustain from shocks and are not able to take advantage to opportunities given the various resources in the community.
\end{abstract}

Keywords: Community Based Monitoring System (CBMS), Community Development, Socio-Economic Scale, Economic Well-Being

\section{Introduction}

\subsection{Background of the Study}

In recent years, there have been increasing concerns on the adequacy of traditional macroeconomic statistics, like gross domestic product (GDP) as measures of current and future living conditions. GDP is defined as the market value of all final goods and services produced in a particular year. This property of the GDP does not include non-marketable commodities like government services and benefits derived public facilities, and they are valued at cost rather than market prices. On the other hand, there are commodities not sold and bought in the market, even though they have a market value, these transactions are not counted in the GDP. These instances made GDP an inaccurate measure for economic wellbeing.

In the case of barangay Lumbia, one of the upland barangays in Cagayan de Oro City, Philippines, various economic activities are concentrated in the barangay hall or in the city main road where schools, barangay hospitals, church and few business establishments are situated. Few kilometers away from the main political and business zone, activities are slower and laidback while support services are either insufficient or non-existent. Population is denser in the main zone while the next neighbor at the outskirts is more than 50 meters, and in between are trees and bushes but the usual sight are pasture lands and mountainous terrain. Poverty is also more prevalent at this frontier than near the barangay hall.

Socioeconomic status of the barangay residents is also varied as manifested in their housing typology, nature of employment, educational attainment of their working family members and household income. These observations sprung interest to examine the economic wellbeing of the residents in this barangay using the socioeconomic scale developed in this study.

\subsection{Objectives of the Study}

The study aims to examine the economic wellbeing of the residents in barangay Lumbia, Cagayan de Oro City, Philippines. It intends to develop a socioeconomic scale as a measure of economic wellbeing. 


\section{Review of Related Literature}

\subsection{History of Welfare}

Economists more often use welfare synonymous for wellbeing and sometimes the terms are used interchangeably. The term welfare is famously remembered from the classical utilitarianism slogan, "the greatest happiness for the greatest number". Utilitarianism can often trace back from the time of the Greek philosopher Epicurus but as a specific school of thought was generally credited to Jeremy Bentham. Utilitarianism was developed as a challenge to the current situation a change. The quantitative limitation of Bentham's utilitarianism was reviewed by the three economists that have promulgated the marginal utility revolution, William Stanley Jevons, Carl Menger and Leon Walras. The concept of utility was used to explain the rational decision of the consumers in their daily choices. However, the invention of the marginal utility was formalized by Daniel Bernoulli and the first elaborate general theory of marginal utility was from Hermann Heinrich Gossen. It was Gossen's application of marginal utility that turned welfare economists toward egalitarian. The assumption of Gossen's theory, redistribution of wealth is a result of the common goal to maximize the welfare of the community. On the other hand, the numerical property of welfare of the society was often rooted to Arthur Cecil Pigou when he developed Gross Domestic Product and redistribution arrangements like Pigouvian redistribution and Pigovian tax for environment protection. Vilfredo Pareto's famous "Pareto efficiency" was crafted from the concept of utility. It measures social welfare but its analytical framework came from the observations of the individual behavior. Pareto efficiency occurs when arrangements can make at least one individual better off without making another individual worse off. Additional theories on welfare were developed like Kaldor-Hicks efficiency when outcome is efficient when losers are compensated by the gainers, and Abram Bergson's social welfare function.

The limitation of the gross domestic product to capture community welfare has lead reformers, researchers and advocate to initiate tools and policies to measure social welfare.

\subsection{Indicators of Economic Wellbeing}

Inner peace, political stability, strong social network are one far more important than the bills for the goods and services people consume from the income earned. In recent years, welfare becomes less interesting topic because its concepts are closer to unmeasurable. The inaccuracy of measuring economic wellbeing has interest researchers to consider proxy of wellbeing or welfare in terms of utility derived from items such as consumption goods and leisure time. In the study of Blinder et al., (1980), they used income and inequality as measurement of wellbeing. As they suggested, the number derived in the level and distribution of income approximate the economic wellbeing of the people. For one, higher income brings out better living standard as recipients able to change its living arrangements. Second, when income is more equally distributed, society is "better off". However, meaningful interpretation of income distribution is better over multiyear to capture impact of income changes and inequality is more variable for a single year. Third, inequality of income distribution can be measured by deriving the Gini ratio from the Lorenz curve.

The growing realization that GDP is a measure of economic quantity and not economic quality or welfare is seen in the increasing development of economic wellbeing measures. Costanza et al (2009) enumerated new barometer of economic wellbeing as: one, indexes for GDP "corrections"; two, index that measure aspects of wellbeing directly; three, composite indexes that combine approaches; and fourth, indicator suites.

First, Measure of Economic Welfare (MEW) (Nordhaus \& Tobin's, 1972) and further developed Index of Sustainable Economic Welfare (ISEW) (Daly and Cobb, 1989) are alternative gage to crude GDP. The former starts with national output but include value of leisure time, value of unpaid work and account the negative value of environmental damage. Although MEW and ISEW have certain similarities like inclusion of value of unpaid work and negative value of environmental damage, the important differences between the two are: MEW explicit attention for environmental damage costs and natural resource depletion; the explicit attention for the distribution of income, different approach to the calculation of the net capital stock, different approach to non-market activities (like value of unpaid work and omits leisure time), inclusion of public expenditure on defense and deduction of private defense. MEW is an attempt to develop index of sustainable development while ISEW takes into account a wider rate of harmful effects of economic growth.

Second, there are alternative indexes that do not quantify economic activity alone but account the environmental aspect of economic activity like Ecological Footprint (EF) (Wackernagel and Rees, 1996), subjective well-being (SWB) which quantify quality of life, moods and emotions (Diener and Suh, 1999) and happiness as measured in the Gross National Happiness (GNH) (http://www.grossnationalhappiness.com). Third, there are composite indexes that are formulated from set of indicators. For example, Human Development Index (HDI) combines three components: longevity, 
knowledge and decent living standards (UN Development Program, 1990). To measure extent and severity of biodiversity loss, a Living Planet Index (LPI) was developed in partnership with the Zoological Society of London which accounts the indices for marine, terrestrial and freshwater species; and for human utilization of resources and emission of carbon dioxide, Ecological Footprint is employed (wwf.panda.org). Fourth, there are benchmarks of economic wellbeing that leave the reader overwhelmed with numerous indicators, without final aggregation. Calvert-Henderson Quality of Life Indicators which is a result of an extensive six-year study, cover 12 issue areas: education, economy, energy, environment, health, human rights, income, infrastructure, national security, public safety, recreation and shelter (www.calvert-herderson.com). These indicators leave overall elucidation to the reader. Another example is the forty-eight indicators of the United Nations Millennium Declaration which measure progress of the eight international Millennium Development Goals (UN DESA, 2007).

In the study of Osberg \& Sharpe (1995), they recognized the UNDP's HDI as measure of societal wellbeing. However, they pointed out that per capita GDP as the source of the HDl's component on "Access to Economic Resources" is potentially misleading. The authors suggested that "'command over resources' should explicitly identify both average consumption and the aggregate national accumulation of productive resources and should include measures of income distribution and economic security (Osberg \& Sharpe, 1995, p. 312)". The formulating of Index of Economic Well-Being (IEWB) is a representation of the wellbeing of an agent based on four dimensions of economic wellbeing, namely: effective per capita consumption flows, stock of wealth, equality and security. As seen in table 1, each basic component has sub-components and each component is given equal weights in the computation of the index.

Table 1: Components and Variables of the Index of Economic Well-Being (IEWB)

\begin{tabular}{|l|l|}
\hline Basic Component & Subcomponents \\
\hline \multirow{5}{*}{ Consumption flows (0.25) } & Real total consumption (NCU per capita) \\
& Real current government spending on goods and services excluding debt service \\
& (NCU per capita) \\
& + Adjustments for changes in working time, life expectancy and household \\
& economies of scale \\
\hline \multirow{5}{*}{ Stock of wealth (0.25) } & Real capita stock (including housing) (NCU per capita) \\
& Real R \& D stock (NCU per capita) \\
& Real stock of human capital (NCU per capita) \\
& Real stock of natural resources (NCU per capita) \\
& Real net foreign debt (NCU per capita) \\
& Real social cost of environmental degradation (CO ${ }_{2}$ emissions) (NCU per capita) \\
\hline \multirow{2}{*}{ Equality (0.25) } & Poverty intensity (Sen-Shorrocks-Thion Index) \\
& Income inequality (Gini coefficient) \\
\hline \multirow{5}{*}{ Security (0.25) } & Risk from unemployment \\
& Risk to financial security from illness \\
& Risk from single parenthood poverty \\
& Risk from poverty in old age \\
\hline
\end{tabular}

$\mathrm{NCU}=$ National Currency Units (PPP adjusted, converted to US\$)

Source: Osberg \& Sharpe, 1995, p. 329

\section{Methodology}

The methodology adopted is based on the reviews of related literatures and concepts of economic well-being. The development of socio-economic scale is grounded on the principles and laws entails to achieve a defined economic wellbeing.

\subsection{Data Source}

Socio-economic assessment was obtained from available sources of data that provide information on social conditions across Barangay Lumbia. The Census of Population and Housing was utilized as the principal source of secondary data. Other secondary data on social and economic data either was available at the barangay or city or National government agencies such as National Statistics Office (NSO), National Statistical Coordination Board (NSCB), Department of Education (DepEd), Department of Health and Department of Social Welfare and Development (DSWD) for information on poverty statistics, education, employment, enrolment in public programs, crime, etc. The Community-Based Monitoring System (CBMS) was also employed as a means to gather primary data not covered in the secondary sources. 


\subsection{Development of Socio-Economic Scale}

The components of the Socioeconomic Scale (SES) are housing, poverty, employment and educational attainment. Every component has respective score. This is further discussed in the next paragraph.

The housing tenure score of the scale is the percentage of all occupied housing units that are owner occupied. It excludes group quarters (e.g., military quarters, dormitories, or prisons). The housing tenure score, then, reflects the relative level of owner-occupied housing versus renter-occupied housing across Barangay Lumbia. The housing tenure component is suggestive of the relative wealth and permanence of the residents in an area and offers insight into the degree of local control of a vitally important resource.

The poverty score includes two equally weighted components: the percentage of all persons in poverty and a measure of poverty level and intensity. Poverty status is determined at a national level by the NSCB as a function of family income and family size. The number of persons below the poverty level is the sum of the number of persons in families with incomes below the poverty level and the number of unrelated individuals with incomes below the poverty level. Poverty status will not be determined for institutionalized persons, persons in military group quarters and unrelated individuals under fifteen years of age.

The first component in the poverty score, the percentage of all persons with income below the poverty level, is the ratio of persons with incomes above the poverty level to those with incomes below the poverty level. The second component of the poverty score indicates the relative intensity of poverty of those individuals with incomes below the poverty level. Three variables are combined to capture the intensity of poverty within a given area, using the following formula:

$S=\Sigma[(1 * X),(3 * Y),(9 * Z)]$

where: $S=$ poverty intensity

$X=$ percentage of persons with incomes between $75 \%$ and $99 \%$ of the poverty level

$Y=$ percentage of persons with incomes between $50 \%$ and $74 \%$ of the poverty level

$Z=$ percentage of persons with incomes less than $50 \%$ of the poverty level

The multiplication factors of 1,3 , and 9 are used to emphasize the intensity of poverty by placing greater weight on the highest poverty levels. These factors help to stretch out the range of numbers and create a greater distance between incomes that are just below the poverty level and those that are far below the poverty level. More linear factors of 1, 2, and 3 do not place enough emphasis on the higher levels of poverty to provide a score reflective of poverty intensity.

Education was reflected by a cumulative educational attainment score weighted toward higher levels of educational attainment. Education was assessed in the census data for all persons twenty-five years of age and older. Unlike other components of the scale, the census universe for educational attainment is all persons, including prisoners, and is reported in a way that does not allow for isolation of incarcerated populations. The education score is calculated by multiplying the percentage of persons in each of the seven census data education categories by a factor that increases by 1 at each higher level and then summing the products.

$$
S=\sum[A,(B * 2),(C * 3),(D * 4),(E * 5),(F * 6),(G * 7)]
$$

where: $\mathrm{S}=$ educational attainment score

$A=$ percentage of persons with less than a sixth grade education

$\mathrm{B}=$ percentage of persons with less than a high school education, no diploma

$C=$ percentage of persons who are high school graduates or the equivalent

$D=$ percentage of persons with some college, no degree

$E=$ percentage of persons with an associate/vocational/technical degree

$F=$ percentage of persons with a bachelor's degree

$\mathrm{G}=$ percentage of persons with a graduate or professional degree

The employment score is the percentage of the civilian labor force that is employed and is the inverse of the percentage of persons who are unemployed. All civilians fifteen years old and older are classified by the NSCB (April 2005) as unemployed if they are:

1. without work, i.e., had no job or business during the basic survey reference period; AND

2. currently available for work, i.e., were available and willing to take up work in paid employment or selfemployment during the basic survey reference period, and/or would be available and willing to take up work in paid employment or self-employment within two weeks after the interview date; AND

3. seeking work, i.e., had taken specific steps to look for a job or establish business during the basic survey reference period; OR not seeking work due to the following reasons: (a) tired/believe no work available, i.e., 
the discouraged workers who looked for work within the last six months prior to the interview date; (b) awaiting results of previous job application; (c) temporary illness/disability; (d) bad weather; and (e) waiting for rehire/job recall.

The basic survey reference period for the LFS is the past week or the week before the interview date. As used here, the universe for employment excludes those not "in the labor force" and those in the armed forces. As measured by the NSCB, unemployment provides a well-defined but somewhat narrow view of the status of the labor force. Since it is limited to individuals who are actively seeking work, the measure is often inaccurate in areas of chronic unemployment where frustrated workers have dropped out of the labor force. Such workers cannot be identified using only census data. These data report employment and labor force participation for those between the ages of 15 and 65 , as well as for those over 65 years of age, but the percentage of persons within these groups who are not in the labor force is not restricted to frustrated workers who have dropped out, but may include early retirees and others who are not part of the labor force by choice.

Standardized scores were calculated for each component score before were combined into a single scale. Standardized scores, often referred to as " $Z$ " scores, indicate the number of standard deviations above or below the mean that a particular observation falls. To ensure that outliers do not have undue influence on the distribution range of any score, each standardized score was be normalized to a base of 100 using two standard deviations as reference points. The individual component scores were combined into a single socioeconomic scale, which was normalized to a base of 100.

The socioeconomic scores were reported on a seven-point categorical scale, with 1 being the lowest socioeconomic score and 7 being the highest. The ordinal scale was derived from the continuous scores, divided into categories based on the number of standard deviations from the mean of the scale. A rating of 1 is a very low socioeconomic score and includes those scores at least two or more standard deviations below the mean (i.e., standard deviation $>-2$ and $<-1$ ); 3 is a medium-low score (standard deviation $>-1$ and $<-0.5$ ); 4 is a medium score (standard deviation $>-0.5$ and $<0.5$ ); 5 is a medium-high score (standard deviation $\geq 0.5$ and $<1$ ); 6 is a high score (standard deviation $\geq 1$ and $<2$ ); and 7 is a very high score (standard deviation $\geq 2$ ).

While income is a commonly used indicator of socioeconomic status and well-being, it was included in the socioeconomic scale for two reasons: (1) most of the variables in the scale are expected to be closely correlated with income, and (2) income measures at the barangay level are absent from the NSO census data and collecting them through surveys are problematic. NSCB reports income but in a variety of tables and formats which are also not reported at the barangay level. As an additional potential source of complication, analysis of aggregate income might indicate that pockets of households with extraordinarily high income throughout Barangay Lumbia can significantly distort the real distribution of income within aggregations, making average income measures-whether household, family, or per capita-inappropriate as relative indicators of the socioeconomic status of individuals within a particular area. Average income measures are best suited only as a means for expressing total income in an area in relative terms. Thus, direct income measures will not be included in the socioeconomic scale.

\section{Results and Discussion}

\subsection{Socio-economic Components}

The United Nations Member States (UN HABITAT, 1996) defined housing as an "adequate privacy, adequate space, physical accessibility, adequate security, security of tenure, structural stability and durability, adequate lighting, heating and ventilation, adequate basic infrastructure, such as water-supply, sanitation and waste-management facilities, suitable environmental quality and health-related factors, and adequate and accessible location with regard to work and basic facilities: all of which should be available at an affordable cost." From this comprehensive representation of housing, housing is imagined into four layer model from the core is the home which is perceived to be a refuge from the outside (Kearns et al., 2000), then dwelling which should protect inhabitants from indoor nuisances (Evans, 2003), followed by community which shapes the inhabitants' sense of trust, build support group and social cohesion (Altgeld, 2004) and finally, immediate housing environment which involves quality urban design (Cohen et al., 2003). The linkage of adequate housing and health is strong that most household viewed housing tenure as one of the factors which protects the dwellers from health related concerns. This is also regarded as sustainability indicators (Hart, 2000).

Housing tenure score of the 30 sitios in Barangay Lumbia is shown in Table 2. As revealed, the second column reflects the percent of house owners to the total household respondents per sitio while the third column signifies the mean housing tenure score of each sitio. Housing tenure score ranges from zero to one. A zero mean housing tenure 
score means that all household respondents within a sitio occupied housing units they do not owned, as seen in sitio Upper Dolawon. On the other hand, a mean housing tenure score of one indicates that all household respondents in a sitio occupied their own houses, as shown in sitios Impaumbo and La Mirande.

On the same table, poverty score per sitio arrays from zero to nine. Each sitio has non-poor households. However, many households within a sitio encountered poverty and its intensity differs from one household to another. As majority of the households in the sitio experienced high poverty intensity, mean poverty score increases. For instance, there might be a sitio with few poor households; however, these poor households belonging to persons earning less than $50 \%$ from the poverty level which affect the mean poverty score of the sitio. This is evident in most sitios with high incidence of poor households, like: Zone 2, Cabula, Baluarte, Upper Kiam-is, Upper Dolawon, Lower Kiam-is, Malubog, Pahiron, Impaumbo, Patpat, Lower Dolawon and Xavier Ecoville. These are reflected in column 2.

Kofi Annan of United Nations associated ill health and poverty as biggest enemy for developing countries. Filipino poor would die earlier, as poverty incidence in 2013 APIS marks $24.9 \%$ (NSCB, 2013), yet $63.1 \%$ of the health spending in the Philippines is heavily shouldered by private sources. Poverty is a widely tackled issue that recent poverty researchers deepen their understanding on why poverty occurs and how to improve the effectiveness of poverty reduction policies. Three main fronts of poverty focus on poverty dynamics (Barrett, 2005), multidimensional concepts (Baulch, B. and Davis, P. 2007) and measures of poverty and cross-disciplinary research. The dynamism involved in poverty as a factor of seasonality of income, consumption, fluctuation of access to food and health services loomed to be important aspect of poverty. Even in the study of Beckley et al. (2002), they presented that community viewed subsistence lifestyle and economic well-being as high priority and in terms of sustainability, community ranked $\%$ of meat needs met through subsistence and prevalence of low income residents as medium priority.

Table 2: Housing Tenure and Poverty

\begin{tabular}{|c|c|c|c|c|}
\hline \multirow[b]{2}{*}{ Sitio } & \multicolumn{2}{|c|}{ Housing Tenure } & \multicolumn{2}{|c|}{ Poverty Tenure } \\
\hline & $\begin{array}{c}\text { Percentage of House } \\
\text { Owners }\end{array}$ & Mean Housing Tenure Score & $\begin{array}{c}\text { Percentage of Poor } \\
\text { Households }\end{array}$ & $\begin{array}{l}\text { Mean Poverty } \\
\text { Score }\end{array}$ \\
\hline Zone I & 68.42 & 0.68 & 15.79 & 1.10 \\
\hline Zone II & 70.83 & 0.76 & 58.33 & 4.00 \\
\hline Zone III & 42.11 & 0.42 & 31.58 & 2.05 \\
\hline Cabula & 16.67 & 0.17 & 66.67 & 4.17 \\
\hline Baluarte & 68.00 & 0.68 & 68.00 & 5.28 \\
\hline Upper Kiam-is & 66.67 & 0.67 & 66.67 & 5.00 \\
\hline Upper Dolawon & 0.00 & 0.00 & 100.00 & 7.5 \\
\hline Lower Kiam-is & 55.56 & 0.56 & 88.89 & 6.00 \\
\hline Malubog & 66.67 & 0.67 & 66.67 & 5.00 \\
\hline Sta. Cruz & 62.50 & 0.63 & 50.00 & 4.13 \\
\hline Mabuhay & 50.00 & 0.50 & 20.00 & 1.80 \\
\hline Upper Palalan & 56.25 & 0.56 & 40.63 & 2.44 \\
\hline Narulang & 50.00 & 0.50 & 50.00 & 3.50 \\
\hline Pahiron & 33.33 & 0.33 & 66.67 & 4.67 \\
\hline Impaumbo & 100.00 & 1.00 & 83.33 & 5.00 \\
\hline Patpat & 76.47 & 0.76 & 52.94 & 3.59 \\
\hline Lower Dolawon & 50.00 & 0.50 & 60.00 & 4.00 \\
\hline Airport & 35.29 & 0.35 & 26.47 & 1.68 \\
\hline Crossing & 17.65 & 0.18 & 44.12 & 3.44 \\
\hline San Isidro & 66.67 & 0.67 & 50.00 & 3.00 \\
\hline Lower Palalan & 54.84 & 0.55 & 41.94 & 2.71 \\
\hline Xavier Ecoville & 81.01 & 0.81 & 63.29 & 4.25 \\
\hline La Buena Vida & 73.68 & 0.74 & 5.26 & 0.21 \\
\hline Frontiera Subd. & 80.00 & 0.80 & 0.00 & 0.00 \\
\hline Montana Vista & 75.00 & 0.75 & 6.25 & 0.47 \\
\hline Lezzandra Subd & 80.00 & 0.80 & 0.00 & 0.00 \\
\hline Portico 1 & 72.73 & 0.73 & 4.55 & 0.14 \\
\hline Portico 2 & 90.91 & 0.91 & 9.09 & 0.82 \\
\hline Vista Grande & 87.50 & 0.88 & 0.00 & 0.00 \\
\hline La Mirande & 100.00 & 1.00 & 0.00 & 0.00 \\
\hline
\end{tabular}

Earliest account on the relationship between education and economic development to economic growth started early 1960s (Schultz, 1961; Denison, 1962) but early investigation on the hours spent by labor and physical capital to production was made by Solow (1957), hence, the theory of Solow residual was born. In recent literature, education were associated to positive and significant effect to production (Pachico \& Ashby, 1976) and the gap between private rates to education and social rates is highest in the lower and marginally industrialized middle-income countries Haddad et al. 
(1990). In the Philippines, for age bracket of 17-24 years, where higher proportion of students is enrolled in private schools, this reflects higher privates spending of education. This has resulted to higher probability of college leavers and fewer number of higher school graduates not able to pursue tertiary education.

Sitios which recorded relatively high educational attainment score do not necessarily insinuates a high mean educational attainment score. Mean educational attainment score echoes the educational attainment of the majority like in the case of Xavier EcoVille. Xavier Ecoville, Lessandra Subdivision and Portico 1 posted 7 as the highest educational attainment score in their sitio. Of the three sitios, Xavier Ecoville has the lowest mean educational attainment score as there are residents in the area who are below 25 years old. As listed, Xavier Ecoville and Airport has roughly similar mean educational attainment score even if the former has bigger population than the latter but because both sitios have young inhabitants, mean educational attainment score is low.

On the same table, employment score is listed and differs from 0 to 1 . A sitio which recorded zero employment score has unemployed resident, as seen to greatest number of sitios. On the other hand, a sitio which garnered 1 employment score occupied by employed residents. Mean employment score reflects the ratio of employment to the number of dwellers in the sitio.

Majority of the sitios have unemployed resident as manifested in the third column. Sitios with more than half of the residents who are unemployed lived in Zone 2, Cabula, Upper Kiam-is, Narulang, Xavier EcoVille, Frontiera Subdivision, Portico 2 and La Mirande. This holds true of their low mean employment score. In contrast, Malubog is the only sitio with the highest mean employment score and employment rate.

The human capital theory of Gary Becker linked economic success to the education of the workforce. With this, employability of graduates as viewed by the government, to some extent, is imposed as a role of the higher educational institutions. The significant number of employable graduates eases movement of jobs and financial opportunities, higher preference of tourist destination, facilitate labor movement and increase technology sharing. The image attached to employability is essential that "employment" performance indicator becomes part of the accountability mechanisms of higher education (HEFCE, 2001).

Table 3: Educational Attainment and Employment

\begin{tabular}{|c|c|c|c|c|}
\hline \multirow[b]{2}{*}{ Sitio } & \multicolumn{2}{|c|}{ Educational Attainment } & \multicolumn{2}{|c|}{ Employment } \\
\hline & $\begin{array}{c}\text { Number of Household Respondents } \\
\text { below } 25 \text { years old }\end{array}$ & Average Educational Attainment Score & $\begin{array}{l}\text { Employment } \\
\text { Rate }\end{array}$ & $\begin{array}{l}\text { Average Employment } \\
\text { Score }\end{array}$ \\
\hline Zone I & \begin{tabular}{|c|}
0 \\
\end{tabular} & 2.68 & 69.49 & 0.68 \\
\hline Zone II & 0 & 2.53 & 41.25 & 0.47 \\
\hline Zone III & 3 & 2.28 & 60.00 & 0.61 \\
\hline Cabula & 1 & 1.83 & 46.67 & 0.54 \\
\hline Baluarte & 1 & 2.23 & 53.42 & 0.51 \\
\hline Upper Kiam-is & 0 & 1.80 & 47.62 & 0.49 \\
\hline Upper Dolawon & 0 & 1.50 & 50.00 & 0.50 \\
\hline Lower Kiam-is & 1 & 1.78 & 54.55 & 0.55 \\
\hline Malubog & 0 & 1.17 & 83.33 & 0.83 \\
\hline Sta. Cruz & 0 & 1.79 & 56.00 & 0.54 \\
\hline Mabuhay & 0 & 2.03 & 62.07 & 0.68 \\
\hline Upper Palalan & 1 & 2.07 & 68.00 & 0.69 \\
\hline Narulang & 0 & 3.19 & 40.00 & 0.48 \\
\hline \begin{tabular}{|l|} 
Pahiron \\
\end{tabular} & 1 & 1.44 & 57.89 & 0.59 \\
\hline Impaumbo & 1 & 2.08 & 60.00 & 0.55 \\
\hline \begin{tabular}{|l|} 
Patpat \\
\end{tabular} & 1 & 2.22 & 60.00 & 0.60 \\
\hline Lower Dolawon & 3 & 2.06 & 56.94 & 0.55 \\
\hline Airport & 6 & 2.67 & 51.85 & 0.50 \\
\hline Crossing & 0 & 2.25 & 54.74 & 0.56 \\
\hline San Isidro & 0 & 2.17 & 52.50 & 0.53 \\
\hline Lower Palalan & 2 & 2.20 & 61.04 & 0.58 \\
\hline Xavier Ecoville & 3 & 2.35 & 49.28 & 0.51 \\
\hline La Buena Vida & 0 & 4.22 & 54.66 & 0.58 \\
\hline Frontiera Subd. & 0 & 4.37 & 25.81 & 0.25 \\
\hline Montana Vista & 0 & 4.70 & 57.29 & 0.61 \\
\hline Lezzandra Subd & 0 & 5.20 & 69.23 & 0.70 \\
\hline Portico 1 & 0 & 5.30 & 62.26 & 0.65 \\
\hline Portico 2 & 0 & 4.57 & 44.00 & 0.36 \\
\hline Vista Grande & 1 & 4.47 & 62.16 & 0.59 \\
\hline La Mirande & 0 & 4.43 & 25.00 & 0.29 \\
\hline
\end{tabular}




\subsection{Socioeconomic Scale}

Community capacity can be framed with wellbeing assessment (Prescott-Allen, 2001), sustainability (Beckley et al., 2002), social cohesion and resilience (Sheppard, S.R.J., 2003) and landscape visualization and stewardship (Meitner, M., 2003). This section discusses the association of community capacity to social cohesion and resilience. Social capital, the dependent variable, includes community social psychological component and community social organization. While, community resilience is the intervening variable which affects the internal and external community's and individual economic viability or existence (Matthews, R.,2003). Economic well-being is assessed with an economic performance index consisting of several community-level employment and income measures, including overall income, occupational composition, job loss, and economic growth.

The study adopted the seven-point categorical scale based on the computed scores as shown in Table 4.

Table 4: Socioeconomic Scale

\begin{tabular}{|l|c|}
\hline Score & Socioeconomic Scale \\
\hline Above 79.21 & 7 \\
\hline From 67.51 to 79.2 & 6 \\
\hline From 55.81 to 67.5 & 5 \\
\hline From 44.11 to 55.8 & 4 \\
\hline From 32.5 to 44.1 & 3 \\
\hline From 20.8 to 32.4 & 2 \\
\hline Less than 20.7 & 1 \\
\hline
\end{tabular}

Employing the categorical scale above, table 5 reveals the lowest and highest recorded socioeconomic scale per sitio and its respective mean socioeconomic scale. Socioeconomic scale ranges from 1 to 7 , a higher scale means relatively better socioeconomic well-being of the household in a sitio. As reflected in column 2, majority of the households in Barangay Lumbia have socioeconomic scale of 3 . However, there are households lower than the socioeconomic scale of most sitios. These households lived in Upper Palalan and Pahiron.

Moreover, certain households in Lessandra Subdivision and Portico 1 encountered comparatively better socioeconomic status than the rest of the sampled household respondents. Further, these subdivisions plus other upscale subdivisions like La Buena Vida, Montana Vista, Portico 2, Vista Grande and La Mirande scored above 4 in their mean socioeconomic scale. As seen in column 4, sitios at the lower gamut are Upper Dolawon, Cabula and Xavier Ecoville. Xavier EcoVille is a resettlement area for Sendong survivors which at this time need continuous assistance.

Table 5: Socioeconomic Scale per Sitio

\begin{tabular}{|l|c|c|c|c|}
\hline Sitio & $\begin{array}{c}\text { Number of } \\
\text { Households }\end{array}$ & $\begin{array}{c}\text { Lowest } \\
\text { Socioeconomic Scale }\end{array}$ & $\begin{array}{c}\text { Highest Socioeconomic } \\
\text { Scale }\end{array}$ & $\begin{array}{c}\text { Average Socioeconomic } \\
\text { Scale }\end{array}$ \\
\hline Zone I & 19 & 3 & 6 & 4.32 \\
\hline Zone II & 24 & 3 & 5 & 4.00 \\
\hline Zone III & 19 & 2 & 6 & 3.74 \\
\hline Cabula & 18 & 2 & 4 & 4.22 \\
\hline Baluarte & 25 & 3 & 6 & 3.00 \\
\hline Upper Kiam-is & 9 & 2 & 5 & 3.00 \\
\hline Upper Dolawon & 2 & 3 & 3 & 3.89 \\
\hline Lower Kiam-is & 9 & 3 & 5 & 4.33 \\
\hline Malubog & 3 & 3 & 5 & 3.88 \\
\hline Sta. Cruz & 8 & 3 & 5 & 3.80 \\
\hline Mabuhay & 10 & 3 & 5 & 3.94 \\
\hline Upper Palalan & 32 & 1 & 6 & 4.00 \\
\hline Narulang & 6 & 3 & 6 & 3.44 \\
\hline Pahiron & 9 & 1 & 4 & 4.17 \\
\hline Impaumbo & 6 & 3 & 5 & 4.25 \\
\hline Patpat & 51 & 2 & 6 & 3.87 \\
\hline Lower Dolawon & 30 & 2 & 5 & 3.50 \\
\hline Airport & 34 & 2 & 6 & 3.35 \\
\hline Crossing & 34 & 2 & 6 & 3.92 \\
\hline San Isidro & 12 & 3 & 5 & \\
\hline
\end{tabular}




\begin{tabular}{|l|c|c|c|c|}
\hline Lower Palalan & 31 & 2 & 5 & 3.80 \\
\hline Xavier Ecoville & 79 & 2 & 5 & 3.29 \\
\hline La Buena Vida & 57 & 2 & 6 & 4.58 \\
\hline Frontiera Subd. & 10 & 3 & 5 & 4.00 \\
\hline Montana Vista & 32 & 3 & 6 & 4.81 \\
\hline Lezzandra Subd & 5 & 4 & 7 & 5.40 \\
\hline Portico 1 & 22 & 3 & 7 & 4.95 \\
\hline Portico 2 & 11 & 2 & 6 & 4.45 \\
\hline Vista Grande & 16 & 2 & 6 & 4.75 \\
\hline La Mirande & 6 & 4 & 5 & 4.50 \\
\hline
\end{tabular}

\section{Summary and Conclusion}

The socio-economic scale based was on four component scores, namely: housing tenure, poverty levels, educational attainment and employment status of each household. Socioeconomic scale is generated thru the combined standardized score of each component, normalized to a base of 100 using two standard deviations as reference points. A seven-point categorical scale was developed, where 1 indicated the lowest socioeconomic score and 7 as the highest. The study found out that majority of the households in barangay Lumbia has socioeconomic scale of 3 . On the other hand, households in upscale subdivisions like; Lessandra Subdivision and Portico 1 positioned at the highest scale of 7 . Findings indicate that the greatest number of the residents in the community has low socio-economic capacity and ability to take advantage to opportunities given the various resources in the community.

The study concludes that the housing tenure scenario and status educational attainment of the working population of Barangay Lumbia mirrors the standing at the regional and national level. However, despite the high labor force participation rate, unemployment and poverty status of the barangay is relatively high compared to the regional and national level. There is 1 out of 5 poor households that are categorized with having a highly intense poverty. In terms of the educational attainment, there is 1 out of 3 household members aged 25 years old and above have attained high school education. Also from the findings, the study determines that socioeconomic scale of the households in the 30 sitios is highly affected by their employment and educational attainment. Moreover, sitios with lower socio economic scale have lower household's economic capacity and geographically located at the periphery farther from the main economic activity of the sitio. Results further signifies that the greatest number of the residents in the community has low capability to collectively sustain from shocks and are not able to take advantage to opportunities given the various resources in the community.

\section{Acknowledgement}

The study is a component of a research title "Carrying Capacity of Barangay Lumbia". The researcher would like to thank Dr. Ester L. Raagas, Project Head of this study and Ms. Catherine Roween C. Almaden, Component Team Leader for their valuable support and suggestions for the betterment of this paper. Also, the researcher would like to extend her gratitude to the members of the faculty at Economics Department of Xavier University-Ateneo de Cagayan for their patience and understanding while the author is finalizing this paper. Lastly, the author would like to express her gratitude to the Xavier University-Higher Education Regional Research Center (HERRC) of Commission of Higher Education (CHED), Philippines for funding this extensive multidisciplinary study.

\section{References}

Altgeld, T. (2004) Gesundheitsfördernde Settingansätze in benachteiligten städtischen Quartieren, Expertise E\&C: Entwicklung und Chancen Junger Menschen in sozialen Brennpunkten. www.eundc.de.

Barrett, C. B. (2005).Rural Poverty Dynamics: Development Policy Implications, in D. Colman and N. Vink (eds), Reshaping Agriculture's Contributions To Society, Blackwell, Oxford.

Baulch, B. and Davis, P. (2007). Poverty Dynamics and Life Trajectories in Rural Bangladesh. Paper presented at the conference on QSquared in Policy. Hanoi, July 7-8, 2007

Beckley, T.; Nadeau, S.; Wall, E.; Martz, D. (2002)a. Multiple Capacities, Multiple Outcomes: Delving Deeper Into the Meaning of Community Capacity. Annual Meet. Rural Sociology. Society, Chicago, Illinois, 14-17 August 2002. http://www.google.com.ph/url ?sa=t\&rct=j\&q=\&esrc=s\&source=web\&cd=1\&ved=0CB0QFjAA\&url=http\%3A\%2F\%2Fjrcd.ca\%2Finclude\%2Fgetdoc.php\%3Fid\% 3D426\%26article\%3D250\%26mode\%3Dpdf\&ei=AKx5UIf9IszLmgXKmIGQAg\&usg=AFQjCNEvTLzKuL_6_Z887ScS_sScHRzjFg

Becker, G.S. (1975). Human Capital. Chicago: Chicago University Press.

Blinder, A. S., Kristol, I., \& Cohen, W. J. (1980). The level and distribution of economic well-being. In The American economy in 
transition (pp. 415-500). University of Chicago Press.

Calvert-Henderson Quality of Life Indicators. <http://www.calvert-herderson.com>

Costanza, R., Hart, M., Talberth, J., \& Posner, S. (2009). Beyond GDP: The need for new measures of progress.

Daly H.E. and J.B. Cobb (1989). For the Common Good, Beacon Press, Boston, pp. 401-455.

Denison, E.F. (1967). Why Growth Rates Differ? The Brookings Institution.

Evans, G.W. (2003). The built environment and mental health, Journal of Urban Health, Vol. 80, No. 4, pp.536-555.

Gross National Happiness <http://www.grossnationalhappiness.com>

Haddad, Wadi D., Carnoy, Martin; Rinaldi, Rosemary \& Regel, Omporn. (1990). Education and Development. USA.

Hart, M. 2000. Sustainable Community Indicator Checklist: Sustainable Measures.North Andover, MA. http://www.sustainablemeasures. com/Indicators/Checklistltself.html

HEFCE. (2001). Indicators of Employment [Report 01/21]. Bristol: Higher Education Funding Council for England.

Kearns, A., Hiscock, R., Ellaway, A. and Macintyre, S. (2000) Beyond four walls. The psycho-social benefits of home: evidence from West Central Scotland, Housing Studies, Vol. 15, No. 3, pp.387-410.

Nordhaus, WD and Tobin, J (1972) Is Growth Obsolete? Economic Growth, National Bureau of Economic Research, no 96, New York.

Matthews, R. (2003). The Resilient Communities Project in British Columbia: Identifying the Relationship Between Community Social Cohesion And Economic Change. Univ. British Columbia, Resilient Communities Project, Vancouver, BC. http://www.horizons.gc. ca/doclib/matthews_0604_2004.pdf

National Statistical Census Board Fact Sheets, various years. www.nscb.gov.ph

Osberg, Lars \& Sharpe, Andrew (2005) How Should We Measure the "Economic" Aspects of Well Being" Research of Income and Wealth. Series 51, Number 2

Pachico, D.H. \& Ashby J.A. (1976). Investments in Human Capital and Farm Productivity: Some evidence from Brazol, Unpublished Manuscript, Cornell University, Ithaca NY.

Prescott-Allen, R. (2001). The Wellbeing of Nations: A Country-By Country Index of Quality of Life and the Environment. Island Press, Washington, DC.

Schultz, T.W. (1961). - Education and economic growth,Il in Social Forces Influencing American Education. Chicago: National Society for the Study of Education.

Sheppard, S.R.J. (2003). Knowing a sustainable forest when you see one: implications for results-based forestry. For. Chron. 79(5):865875.

Solow, R. 1957. - Technical Change and the Aggregate Production Function, Review of Economics and Statistics,39: 312-320

UN DESA. 2007. The Millennium Development Goals Report. New York: United Nations Department of Economic and Social Affairs.

UN Development Program. 1990. Human Development Report: Overview. New York: Oxford University Press.

UN Habitat (1996) Declaration, 2nd HABITAT Conference, Istanbul.

Wackernagel, M., Rees, W.E. (1996) Our Ecological Footprint: Reducing Human Impact on the Earth, New Society Publishers, Gabriola Island, British Columbia, Canada. Germany edition with updated data, 1997. Birkhäuser, Basel, 1997 